\title{
Increasing the Efficiency of Recurrent Selection for Yield in Maize
}

\author{
Mohamed M. El-Rouby, Mohamed H. El-Sheikh and Shaimaa M. Awad Allah ${ }^{1}$
}

\begin{abstract}
The objectives of the present study were to increase the efficiency of recurrent selection within the "Composite-21" variety of maize using selection index to increase the precession of the evaluation of $S_{1}$-families. Ninety $S_{1}$ families were evaluated in six sets, each set included $15 S_{1}$ families replicated three times. Data were collected for yield, yield components characters and agronomic characters to carry out six selection methods. One method is based on ear yield alone and the other five methods were based on selection index. Estimation of environmental $\left(\sigma^{2}\right)$, phenotypic $\left(\sigma_{\mathrm{ph}}^{2}\right)$ and genotypic $\left(\sigma_{\mathrm{g}}^{2}\right)$ variances and broad scense heritability (H \%) were calculated for each trait to predict the genetic gain from different selection methods. Phenotypic and genetic correlations among traits were calculated to examine the possibility of indirect selection for yield using some characters which are highly correlated with yield. Heritability estimates were intermediate (41$55 \%$ ) for ear yield, 100-kernel weight and kernel depth and more than $70 \%$ for number of rows/ ear, plant and ear heights. The genetic correlations for yield with the other characters were in general intermediate.
\end{abstract}

Based upon the expected advance from selection, the expected gain which is coming from the indices ranged between (5.58-19.13\%) comparing with the expected gain which is coming from yield alone $(16.43 \%)$. So, the use of indices was slightly superior to selection based on yield alone. The actual improvement in yield is $9 \%$ for selection based on yield alone, $8 \%$ for selection index based on yield and all characters, $3 \%$ for the index based on yield and ear characters and $1 \%$ for the index based on yield and vigor characters. The predicted advance from selection was higher than the actual advance.

Key words; Zea mays, recurrent selection, selection index, $S_{1}$ families, Heritability.

\section{INTRODUCTION}

Maize (zea mays L.) is one of the most important cereal crops in the world and Egypt. It comes after wheat and rice with respect to relative importance. In Egypt, it was used as a staple food for farmers. However, it is used mainly as a feed crop for both animal and poultry industry. The local production of maize in Egypt would not satisfy the local consummation. The increase of population reached to 92 million in 2015, the Egyptian Government faces a shortage in meat supply for the Egyptian population. This shortage in meat supply was accompanied by a reduction in the local currency. Therefore, the effort was concentrated on supplying the meat from animal and poultry from locally maize. This plan could not succeed unless production should increase locally.

The Ministry of Agriculture is encouraging the Egyptian farmer to increase the productivity of maize to satisfy the needs of animal and poultry industry through increasing the area grown by maize and growing high yield maize cultivars.

At the beginning of the $20^{\text {th }}$ century, Shull (1908) discovered the new phenomena, and it was latter labeled heterosis, by crossing between two homozygous inbred lines. However, hybrid vigor was not used commercially until Jones (1924) suggested the use of double cross hybrid commercially instead of single cross hybrids. Since that time, the area cultivated by double cross increased and latter it was possible to develop cheap seed of single cross hybrid. Maize breeder devoted their efforts to increase the yield of the new hybrids by increasing the yield of base populations from which they isolate their inbred lines. Sprague and Brimhall (1950) developed new method to increase the probability of isolating promising inbred lines and called it recurrent selection. The objective of this method was to increase the probability of developing a new recombining between loci and overcome the possibility of fixing the promising genotypes. Since that, several versions of recurrent selection were developed with the objectives: (a) constructing sources for developing new recombination between desirable loci in order to be used as base populations to develop new hybrids, (b) to be used as improved cultivars in countries where it is not possible to grow hybrids.

Several types of recurrent selection were developed varying on the type of isolated families. Consequently, the advance from selection would depend upon the type of isolated families and heritability.

The published results showed that the most efficient type of recurrent selection was $\mathrm{S}_{1}$ or $\mathrm{S}_{2}$ recurrent selection. Maize breeder developed the equation to predict the advance from selection as follows:

$\Delta \mathrm{g}=\left(\right.$ Selection differential) $\mathrm{h}^{2}$ where,

Selection differential $=$ Mean of selected families mean of the original population. Heritability $\left(\mathrm{h}^{2}\right)$ of yield is relatively low. To increase $\Delta \mathrm{g}$ for yield the use of other characters highly correlated with yield and less affected by environment is expected to be more efficient indicator for yield. This character is called an aid

${ }^{1}$ Department of Agronomy, Faculty of Agriculture (El-Shatby),

Alexandria University

Received April 9, 2017, Accepted May 11, 2017. 
character for selection. Instead of using one aid character, several plant characters could be used as aid characters.

Smith (1936) and Hazel and Lush (1942) suggested the use of selection index where information will be collected for several characters on the evaluated families in order to select the best families.

The objective of the index either to select the genetic worth of the selected families when their values are function of several characters, i.e., yield and quality characters or when the values of the families are function of the yield alone as in the present study. The selection index in the present study was used to evaluate the genetic worth of the families for yield and the other studied characters given that yield has the economic value and the other characters are used as help to show their genetic worth.

The objectives of the present investigation were:

(1)To study the efficiency of selection for yield with a composite maize variety.

(2) To maximize gain from selection using all possible information collected on the evaluated families which include yield and yield components and agronomic characters.

(3)To examine the possibility of selection for yield using some characters which are highly correlated with yield (indirect selection).

\section{MATERIALS AND METHODS}

\section{Field Procedures}

The present investigation was conducted at the Alexandria Agricultural Research Station, Alexandria University, Alexandria, during the summer seasons of 2010- 2013. The maize population under study was "Composite-21" variety, developed by Maize Research Program, Agriculture Research Center, Ministry of Agriculture. This composite is yellow-seeded and was excluded from their production program.

\section{Isolation of $S_{1}$ Families}

In the summer season of 2010, one strip was of 100 rows, each row was 5 meters along and $70 \mathrm{~cm}$ apart was planted with the "composite-21" variety and $50 \mathrm{~cm}$ distance a part between hills. Before flowering, 300 plants were selected and selfed to produce $S_{1}$ seeds. At harvest, the heaviest 90 selfed ears were selected and each ear was considered as $\mathrm{S}_{1}$-family.

\section{Family-Evaluation Trial:}

In summer season of 2011, The 90 families were split into six sets; each included $15 \mathrm{~S}_{1}$-families. Each set was handled independently. The $15 \mathrm{~S}_{1}$-families from each set were grown in an experiment arranged in a randomized complete block design with three replications. The plot size was $2.8 \mathrm{~m}^{2}$ representing one row of 4.0 meters long and $0.7 \mathrm{~m}$ apart consisting of 14 single hill plants. All recommended cultural practices for maize under Alexandria conditions were followed. At harvest, some characters were measured on each plot and these characters were, ear yield (g/ plot), ear length $(\mathrm{cm})$, ear width $(\mathrm{cm})$, number of rows/ ear, weight of 100-kernels (g), moisture percent (\%), kernel depth $(\mathrm{cm})$, plant height $(\mathrm{cm})$, ear height $(\mathrm{cm})$ and the ear leaf area $\left(\mathrm{cm}^{2}\right)$.

Statistical analysis was calculated for each set and then the six sets will combined in one ANOVA. Both replications and families were considered random, also the error component was considered random. The form of the combined analysis is presented in Table (1):

The analysis of variance for all sets for each character were combined to calculate the two variance components, for $S_{1}$ families, $\hat{\sigma}_{\mathrm{e}}^{2}$ and $\hat{\sigma}_{\mathrm{F}}^{2}$ and to translate them in terms of genetic and environmental variances. The genetic variance $\sigma_{\mathrm{g}}{ }^{2}$ for $\mathrm{S}_{1}$-families will be that:

$\sigma_{\mathrm{g}}^{2}=\frac{\mathrm{M} 2-M_{1}}{3}$; and its expected value would be; $\sigma_{\mathrm{g}}{ }^{2}=$ $\mathrm{a} \sigma_{\mathrm{A}}^{2}+\mathrm{b} \sigma_{\mathrm{D}}^{2}$

Where $\mathrm{a}$ and $\mathrm{b}$ are unknown and their values would depend on the unknown gene frequency of the original population. Assuming that dominance variance $\left(\sigma_{\mathrm{D}}{ }^{2}\right)$ is less important than additive genetic variance, Hallauer and Miranda, (1981) so the expected value of $\sigma_{\mathrm{g}}{ }^{2}\left(\mathrm{~S}_{1}\right)$ would be reduced to;

Table 1. form of combined analysis of variance over the six sets for the $S_{1}$-families evaluated in RCBD

\begin{tabular}{llll}
\hline Source of variances & d.f & M.S & E.M.S \\
\hline Sets & 5 & & \\
Replications / sets & 12 & & $\sigma_{\mathrm{e}}{ }^{2}+3 \sigma_{\mathrm{F}}{ }^{2}$ \\
Families / sets & 84 & $\mathrm{M}_{2}$ & $\sigma_{\mathrm{e}}{ }^{2}$ \\
Combined Error & 168 & $\mathrm{M}_{1}$ & \\
\hline
\end{tabular}

Where,

$\sigma_{\mathrm{e}}{ }^{2}=$ variance components for error.

$\sigma_{\mathrm{f}}^{2}=$ variance components for $\mathrm{S}_{1}$-families.

$\mathrm{r}=$ number of replications. 
$\sigma_{\mathrm{g}}^{2}\left(\mathrm{~S}_{1}\right)=\sigma_{\mathrm{A}}^{2}$; the amount of bias in the estimate of $\sigma_{\mathrm{A}}{ }^{2}$ would be unknown.

$\sigma_{\mathrm{e}}^{2}=\mathrm{M} 1$

$\sigma_{\mathrm{ph}}^{2}=\sigma_{\mathrm{g}}^{2}+\sigma_{\mathrm{e}}^{2} / 3$

Heritability among $\mathrm{S}_{1}$ families in broad-scense will be:

- Heritability $(\mathrm{H})=\sigma_{\mathrm{g}}{ }^{2} / \sigma_{\mathrm{ph}}{ }^{2}$ Hallauer and Miranda, (1981) where;

- Predicted selection response was calculated using the formula given by Falconar (1981) as follows:

$\Delta \mathrm{G}_{(\alpha)}=\mathrm{K}_{\mathrm{a}} \cdot \sigma_{\mathrm{ph}} \cdot \mathrm{H}$

Where;

$\mathrm{K}_{\mathrm{a}}=$ the selection differential for $\alpha$ selection intensity $(\mathrm{k}=\mathrm{a}$ constant based on selection intensity in standard deviation units) Hallauer and Miranda, (1981).

$\sigma_{\mathrm{ph}}=$ square root of phenotypic variation.

- The percentage of predicted genetic advance under selection response (G\%) was calculated as;

$\mathrm{G} \%=\frac{\Delta \mathrm{G}}{\overline{\mathrm{X}}}$

Where; $\overline{\mathrm{X}}=$ the overall mean.

\section{Phenotypic and Genotypic correlations:}

The correlation between traits was calculated by the estimation of the phenotypic and genotypic covariance between pairs of traits according to Betran (1999)

Genotypic correlation between " $X_{1} "$ and " $X_{2} "=$

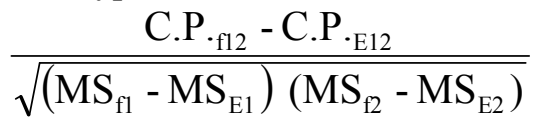

Phenotypic correlation between " $X_{1}$ " and " $X_{2}$ " = $\frac{\text { C.P. }{ }_{\mathrm{f} 12}}{\sqrt{\left(\mathrm{MS}_{\mathrm{f} 1}-\mathrm{MS}_{\mathrm{E} 1}\right)}}$

\section{Selection Procedures}

Based on the statistical analysis, six selection procedures were practiced according to the following criteria:

I- Selection is based on ear yield alone.

II- Selection is based on selection index consisted of ; ears yield, plant height, ear height, ear leaf area, ear length, ear width, kernel depth, 100-kernel weight and number of rows/ear (index of yield and all characters)

III- Selection is based on selection index consisted of; ears yield, ear length, ear width, kernel depth, 100kernel weight and number of rows/ear (index of yield and ear characters).
IV- Selection is based on selection index consisted of; ears yield, plant height, ear height and ear leaf area (index of yield and vigor characters).

$\mathrm{V}$ - Selection is based on selection index consisted of; ear length, ear width, kernel depth, 100-kernel weight and number of rows/ear (index of ear characters only).

VI- Selection is based on selection index consisted of plant height, ear height and ear leaf area (index of vigor characters only)

The index values for the six selection methods were calculated for each family and then the highest two families within each set were identified resulting in a selection intensity of $13 \%\left(\frac{2}{15}\right)$.

In the present study, the economic weight was substituted by relative information weight corresponding to the weight given to the tested families.

Three optimum selection indices were calculated in this study using different information weight, for example, the equation for the construction of the optimum selection index involving three traits having equal information weight is as follows:

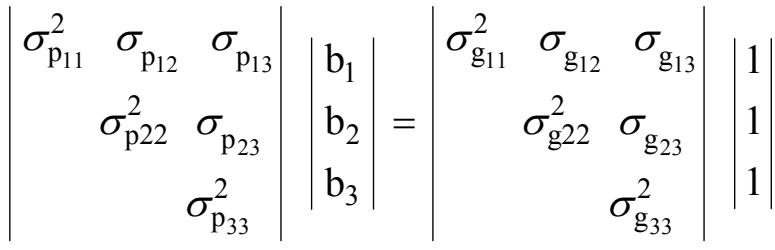

Phenotypic matrix matrix Economic $[\mathrm{P}]$ Genotypic [G] weight [A]

The index weights were calculated from the following equations:

$[\mathrm{P}]^{-1}[\mathrm{P}][\mathrm{B}]=[\mathrm{P}]^{-1}[\mathrm{G}][\mathrm{A}]$

$[B)=[P]^{-1}[G][A]$ where $P^{-1}$ is the inverse matrix for $[\mathrm{P}]$

\section{Formation of synthetics:}

In summer season of 2012, equal seed numbers of the selected $\mathrm{S}_{1}$-families for each selection method, two selection method are based on selection index for ear characters only and vigor characters only were discarded because of their low expected advance from selection, were bulked and each bulk was planted in an isolation field and the plants were allowed for random matting. At maturity, ears from each population were harvested separately resulting in the four new $\mathrm{C}_{1}$ synthetics. 


\section{Synthetics Evaluation:}

In the summer season of 2013, the four cycles of the different selected synthetics from the population (composite-21) in addition to the original population $\left(\mathrm{C}_{0}\right)$ and the check cultivar single cross Giza 168 (yellow seeds and late maturity) were evaluated in a randomized complete block design with twenty replications according to Gomez and Gomez (1984), using SAS program version9,13 (2007). Means were compared, using least significant difference (LSD) value at $\mathbf{P} \leq 0.01$. Each plot consisted of one row four meters long and $70 \mathrm{~cm}$ apart with 10 single-plant hills. All recommended cultural practices for maize crop were followed.

\section{RERSULTS AND DISCUSSION}

\section{Family Evaluation Trail:}

Evaluation of the different families was used in estimating phenotypic and genotypic variances for the studied characters. In addition, these estimates were used in identifying top yielding families. The obtained results were used to calculate the genotypic and phenotypic estimates in the population under study.

Table (2) summarizes the analysis of variance (ANOVA) for the different characters for the $\mathrm{S}_{1}$ families. Differences among the families were significant at 0.01 level of probability for all the studied characters. These results may indicate the presence of genetic variability within the base population"Composite-21" variety.

\section{Estimation of Heritability:}

In the present study, the estimates of heritability were considered in broad - scense because the genetic variance among $S_{1}$ lines is due to both additive $\left(\sigma_{A}^{2}\right)$ and dominance $\left(\sigma^{2}\right)$ variances and it is not possible to detect the amount of dominance variance bias.

Heritability estimates were very high (Table 3 ) for number of rows/ear, plant and ear heights because the genotypic variance $\left(\sigma_{\mathrm{g}}^{2}\right)$ for these characters was 2.5 times the environmental variance $\left(\sigma_{\mathrm{E}}^{2}\right)$. Ear leaf area had a high estimate of heritability because of its highly genetic variance $\left(\sigma_{\mathrm{g}}^{2}\right)$. Intermediate estimates, however, were calculated for ear yield/plot, 100-kernel weight and kernel depth. Ear length and ear width had a low estimates of heritability.

Hallauer and Miranda, (1981) summarized the estimates of the heritability from several maize populations. They found that the heritability estimates ranged between 0.50 and 0.70 for plant height.

Table 2. Analysis of variance for the family-evaluation trails for the $S_{1}$-families isolated from "Composite-21" variety for yield and yield components and agronomic characters in 2011 season

\begin{tabular}{|c|c|c|c|c|c|c|c|c|c|c|}
\hline \multirow[t]{2}{*}{ S.O.V. } & \multirow[t]{2}{*}{ d.f. } & \multicolumn{6}{|c|}{ Yield and yield components } & \multicolumn{3}{|c|}{ Agronomic characters } \\
\hline & & $\begin{array}{c}\text { Ear yield } \\
\text { (g/plot) }\end{array}$ & $\begin{array}{c}\text { Ear length } \\
\text { (cm) }\end{array}$ & $\begin{array}{c}\text { Ear } \\
\text { width } \\
\text { (cm) }\end{array}$ & $\begin{array}{c}\text { No. of } \\
\text { rows/ ear }\end{array}$ & $\begin{array}{l}\text { 100-kernel } \\
\text { weight (g) }\end{array}$ & $\begin{array}{c}\text { Kernel } \\
\text { depth } \\
\text { (cm) }\end{array}$ & $\begin{array}{c}\text { Plant } \\
\text { height } \\
\text { (cm) }\end{array}$ & $\begin{array}{c}\text { Ear } \\
\text { height } \\
\text { (cm) }\end{array}$ & $\begin{array}{c}\text { Ear leaf } \\
\text { area } \\
\left(\mathrm{cm}^{2}\right)\end{array}$ \\
\hline Sets & 5 & 3478240 & 96.19 & 2.86 & 5.95 & 182.56 & 0.201 & 13525 & 4182 & 81428 \\
\hline Replications/sets & 12 & 277923 & 9.51 & 0.37 & 2.42 & 16.25 & 0.015 & 1602 & 585 & 9268 \\
\hline Families/ sets & 84 & $277182 * *$ & $12.23 * *$ & $0.98 * *$ & $6.65^{* *}$ & 29.71 ** & $0.017^{* *}$ & $698^{* *}$ & $216^{* *}$ & $10044 * *$ \\
\hline Combined error & 168 & 144510 & 7.97 & 0.60 & 1.87 & 13.31 & 0.008 & 189 & 56 & 4459 \\
\hline
\end{tabular}

**; indicates significance at 0.01 level of probability.

Table 3. Estimates of environmental variance $\left(\hat{\sigma}_{\mathrm{E}}^{2}\right)$, phenotypic variance $\left(\hat{\sigma}_{\mathrm{ph}}^{2}\right)$, genetic variance $\left(\hat{\sigma}_{\mathrm{g}}^{2}\right)$ and broad-sensce heritability $(\mathrm{H} \%)$ among the mean of $S_{1}$-families for yield and yield components and agronomic characters

\begin{tabular}{lcccc}
\hline Character & $\hat{\sigma}_{\mathrm{F}}^{2}$ & $\hat{\sigma}_{\mathrm{ph}}^{2}$ & $\hat{\sigma}_{\mathrm{g}}^{2}$ & $\mathbf{H \%}$ \\
\hline yield and yield components & & & & \\
Ear yield (g/ plot) & 48170 & 92394 & 44224 & 47.86 \\
Ear length (cm) & 2.66 & 4.08 & 1.42 & 34.8 \\
Ear width (cm) & 0.2011 & 0.3272 & 0.1261 & 38.54 \\
No. of rows/ ear & 0.6256 & 2.2166 & 1.5910 & 71.78 \\
100-kernel weight $(\mathrm{g})$ & 4.4397 & 9.9047 & 5.465 & 55.18 \\
Kernel depth (cm) & $2.78 \times 10^{-3}$ & $5.92 \times 10^{-3}$ & $3.14 \times 10^{-3}$ & 53.04 \\
Agronomic characters & & & & \\
Plant height $(\mathrm{cm})$ & 63.18 & 232.9 & 169.72 & 72.87 \\
Ear height $(\mathrm{cm})$ & 18.81 & 72.07 & 53.26 & 73.90 \\
Ear leaf area $\left(\mathrm{cm}^{2}\right)$ & 1486.5 & 3347.97 & 1861.47 & 55.59 \\
\hline
\end{tabular}

$\sigma_{\mathrm{E}}^{2}=\sigma_{\mathrm{e}}^{2} / 3$ where; $\sigma_{\mathrm{e}}^{2}$ is environmental variance. 
Ear height and silking date; from 0.30 to 0.50 for ear length, ear width and 100-kernel weight and less than 0.30 for yield and kernel depth. These values are in agreement with those of the present investigation.

These results would suggest that selection within the studied population is expected to be promising. Asghar and Mehdi (2010) also showed that the estimates of broad- scense heritability, from S1 families, using an open pollinated sweet maize population, were $(0.38)$ for grain yield, (0.77) for 100-kernel weight, (0.72) for cob length, $(0.67)$ for plant height, and $(0.57)$ for days to silking. Mwimali et al (2015) found that the broad scense heritability estimates from $\mathrm{S}_{1}$ families for grain yield were $95.7,93.5$ and $98.4 \%$ for cycle 0 , cycle 1 and cycle 2, separately, in the population CML395/MBRC5BC.

These findings were higher than the present estimates however; estimates of heritability differ considerably from one study to another depending on the method of evaluation and number of replications.

\section{Phenotypic and Genotypic Variations between Characters.}

Genotypic correlation is due to either pleiotropic effect of genes or close linkage between genes. The latter effect will disapiate by random matting while, the effect of pleiotropic effect will continue and part of the effect of genes. In the present study; the genetic correlation between yield and the other characters could be used as an aid in selection if the correlated characters were lessely affected by environment than yield.

Table (4) showed that the following characters had a highly genotypic correlation with yield; plant height $(0.76)$, ear height $(0.73)$, ear leaf area $(0.81)$, ear width (0.66), number of rows/ear (0.61), 100-kernel weight $(0.71)$ and kernel depth (0.68). These characters could be used as an aid for selection for yield especially if they were less affected by environmental effects. Therefore, the indirect responses from selection of these characters will be reflected on yield.

Ajala et al. (2009) reported that phenotypic and genotypic correlations between tasseling and silking date were very high for all the used selection methods. They also found that among the full-sib families the genetic correlation between plant height and flowering was high.

Other phenotypic correlations though significant in some instances, were lower than \pm 0.52 . Genetic correlations in such case, were lower still..They also showed that the correlations between ear number and grain yield were very high.

Genetic correlations were used to calculate the expected gain from indirect selection. The formula used for calculating response from the indirect selection depends on the heritability for yield and the other characters,

Table 4. Phenotypic (rp) and genotypic (rg) correlation coefficients between all characters under study for the $S_{1}$-families

\begin{tabular}{|c|c|c|c|c|c|c|c|c|c|c|c|c|c|c|c|c|c|}
\hline \multirow[t]{2}{*}{ Character } & $\begin{array}{l}\text { Plant } \\
\text { height }\end{array}$ & \multicolumn{2}{|c|}{ Ear height } & \multicolumn{2}{|l|}{$\begin{array}{l}\text { Ear } \\
\text { area }\end{array}$} & \multicolumn{2}{|c|}{ If Ear yield } & \multicolumn{2}{|c|}{ Ear length } & \multicolumn{2}{|c|}{ Ear width } & \multicolumn{2}{|c|}{$\begin{array}{l}\text { No. of rows/ } \\
\text { ear }\end{array}$} & \multicolumn{2}{|c|}{$\begin{array}{l}\text { 100-kernel } \\
\text { weight }\end{array}$} & \multicolumn{2}{|c|}{$\begin{array}{l}\text { Kernel } \\
\text { depth }\end{array}$} \\
\hline & rg rp & $\mathrm{rg}$ & $\mathbf{r p}$ & rg & $\mathbf{r p}$ & rg & $\mathbf{r p}$ & rg & $\mathbf{r p}$ & rg & rp & rg & $\mathbf{R p}$ & rg & Rp & rg & rp \\
\hline Plant height & - & 0.76 & $0.75^{* *}$ & 0.68 & $0.55^{* *}$ & 0.76 & $0.54^{* *}$ & 0.52 & $0.31^{* *}$ & 0.35 & $0.22^{* *}$ & 0.17 & 0.16 & 0.70 & $0.48^{* *}$ & 0.43 & $0.37^{* *}$ \\
\hline Ear height & & & & 0.47 & $0.39^{* *}$ & 0.73 & $0.49^{* *}$ & 0.41 & $0.21^{*}$ & 0.34 & $0.19^{*}$ & 0.25 & $0.21^{*}$ & 0.51 & $0.36^{* *}$ & 0.41 & $0.34^{* *}$ \\
\hline Ear leaf area & & & & & & 0.81 & $0.51^{* *}$ & 0.74 & $0.43^{* *}$ & 0.63 & $0.38^{* *}$ & 0.25 & $0.19^{*}$ & 0.81 & $0.46^{* *}$ & 0.45 & $0.30^{* *}$ \\
\hline Ear yield & & & & & & & & 0.50 & $0.53^{* *}$ & 0.66 & $0.53^{* *}$ & 0.61 & $0.46^{* *}$ & 0.71 & $0.52^{* *}$ & 0.68 & $0.52^{* *}$ \\
\hline Ear length & & & & & & & & & & 0.40 & $0.62^{* *}$ & $0.06 \square$ & 0.03 & 0.65 & $0.34^{* *}$ & 0.18 & $0.21^{*}$ \\
\hline Ear width & & & & & & & & & & & & 0.69 & $0.42^{* *}$ & 0.34 & $0.25^{* *}$ & 0.28 & $0.25^{* *}$ \\
\hline No. of rows/ ear & & & & & & & & & & & & & & 0.07 & 0.01 & 0.05 & $0.80^{* *}$ \\
\hline $\begin{array}{l}\text { 100-kernel } \\
\text { weight }\end{array}$ & & & & & & & & & & & & & & & & 0.55 & $0.50^{* *}$ \\
\hline
\end{tabular}


also it depends on the correlation coefficient between the direct and indirect characters. The expected gain from indirect selection was calculated from the following equation;

$$
\mathrm{CR}_{\mathrm{y}}=\mathrm{k} \boldsymbol{\sigma}_{\mathrm{py}} \mathbf{h}_{\mathrm{x}} \mathbf{h}_{\mathrm{y}} \mathbf{r}_{\mathrm{A}}
$$

where;

$\mathrm{CR}_{\mathrm{y}}$ : correlated response in trait $\mathrm{y}$.

$\mathrm{k}$ : selection differential in standard deviation units.

$h_{x}: \sqrt{h^{2}}$ for the trait $\mathrm{x}$.

$\mathrm{h}_{\mathrm{y}}: \sqrt{\mathrm{h}^{2}}$ for the trait $\mathrm{y}$.

$\sigma_{\mathrm{py}}$ : the square root of phenotypic variance for the trait $\mathrm{y}$.

Table (5), showed that the relative advance from indirect selection was very high and ranged between $14.3 \%$ to $15.3 \%$ for plant height, ear height and ear leaf area because the estimates of their heritability were high as well as the genetic correlation between these characters with ear yield were high $\left(r_{\mathrm{g}}=0.7\right.$ to 0.8$)$. With respect to ear characters, the relative advance from indirect selection was relatively high and ranged between $7 \%$ to $12.5 \%$ and it was due to their moderate estimates of heritability and the genetic correlation between these characters with ear yield were intermediate $\left(\mathrm{r}_{\mathrm{g}}=0.5\right.$ to 0.7$)$.
None of the studied characters gave a relative response in yield better than yield itself because the genotypic correlation between these characters with yield and their heritability were intermediate.

Habliza (2001) showed that the indirect selection will be more efficient if the heritability of the indirect characters 1.5 times the direct character and the correlation coefficient is 0.8 .

Ajala et al. (2009) concluded the indirect selection for grain yield through ear number will for example, only allow for a maximum of $90 \%$ of the gain if selection were to be for grain yield.

Expected response (G) and expected relative response $(\mathrm{G} \%)$ from selection for yield and the selection indices are presented in Table (6). The advance from selection was high for the selection indices including; yield and all characters (19.13\%) and yield and ear characters $(17.62 \%)$. The relative response for the selection method based on (ear yield g / plot) was also high $(16.43 \%)$.On the other hand, the relative response was small for the selection index including yield and vigor characters $(5.58 \%)$ and almost nil for the indices without yield. So, these two indices were discarded. Based on the expected results, it is recommended that advantage of using selection index might appear in advanced cycles because it had a slight advance over yield alone.

Table 5. Expected indirect response to selection for ear yield $(G)$ and relative indirect response (G\%) for ear yield from selection for some characters

\begin{tabular}{lcc}
\hline Character & $\mathbf{G}^{+}$ & G (\%) \\
\hline Ear length $(\mathrm{cm})$ & 101 & 7 \\
Ear width $(\mathrm{cm})$ & 140 & 9.7 \\
100-kernel weight $(\mathrm{g})$ & 180 & 12.5 \\
No. of rows/ ear & 177 & 12.3 \\
Kernel depth $(\mathrm{cm})$ & 169 & 11.7 \\
Plant height $(\mathrm{cm})$ & 222 & 15.3 \\
Ear height $(\mathrm{cm})$ & 214 & 14.8 \\
Ear leaf area $\left(\mathrm{cm}^{2}\right)$ & 206 & 14.3 \\
\hline
\end{tabular}

+ Expected gain from direct selection for ear yield is $141 \mathrm{~g}$.

++ Mean of the base population for ear yield is $1443 \mathrm{~g} /$ pot.

Table 6. Expected response (G) and expected relative response (G\%) from the six methods of selection based on ear yield only and five selection indices

\begin{tabular}{lcc}
\hline Character & G & G (\%) \\
\hline Ear yield (g/ plot) & 237.12 & 16.43 \\
Yield and all characters & 276.213 & 19.13 \\
Yield and ear characters & 254.32 & 17.62 \\
Yield and vigor characters & 80.65 & 5.58 \\
Ear characters only & 4.668 & 0.32 \\
Vigor characters only & 0 & 0 \\
\hline
\end{tabular}

+ Mean of the base population for ear yield $=1443 \mathrm{~g}$ 
Ajala et al (2009) showed that $\mathrm{S}_{1}$ selection gave the largest predicted response for grain yield (7.69\%) per generation /cycle in FARZ23 population. Badu-Aparaku et al (2012) also, found that the predicted gain/cycle was $350.41 \mathrm{~kg} / \mathrm{ha}$ for grain yield when Striga infested and $250 \mathrm{~kg} / \mathrm{ha}$ when Striga free.

The numbers of common $\mathrm{S}_{1}$ families between the four selection methods are presented in Table (7). None of the selected families was common in the four methods. Six families were common in three methods, while six families were common in two methods. These results would indicate that the four selection methods were similar in identifying the promising lines. This conclusion was supported that the advance from selection from indices were almost similar to selection for yield alone.

\section{Evaluation of The $\mathbf{C}_{1}$-Synthetic Varieties.}

The results showed significant differences among populations for ear yield/plot, ear length, 100-kernel weight, number of rows/ear, number of kernels/row, kernel depth, plant height and ear height Table (8). No significant differences were detected for the characters; ear width, 50\% tasseling, 50\% silking, ear leaf area and number of plants/plot.
As shown in Table (9) and Figure (1) the $C_{1}$ based on yield showed superiority over the $\mathrm{C}_{0}$ for ear yield $\mathrm{kg} / \mathrm{plot}$, ear width, number of rows/ear, 100-kernel weight, kernel depth and plant and ear heights. The superiority of this synthetic over the $\mathrm{C}_{0}$ ranged between 0.02 to 0.14 . The $\mathrm{C}_{1}$ based on yield and all characters was superior to $\mathrm{C}_{0}$ for ear yield $\mathrm{kg} / \mathrm{plot}$, ear width, 100 kernel weight, kernel depth and plant and ear heights and the superiority of this synthetic over the $\mathrm{C}_{0}$ ranged between 0.04 to 0.12 . The superiority of the $C_{1}$ based on yield and ear characters over the $\mathrm{C}_{0}$ ranged between 0.02 to 0.15 whereas, the superiority of the synthetic yield and vigor characters over the $\mathrm{C}_{0}$ ranged between 0.02 to 0.11 .

The present population under selection is (Composite -21). It was developed by the Maize Research Program Research Central, it was excluded from their production program. Its relative yield to the hybrid yield $\frac{1.4}{1.9}=73 \%$. It is suggested that efforts should be devoted to increase the yield of this composite by adding new germplasm to increase the yield of this composite.

Table 7. Number of Common $S_{1}$-families selected based on yield and the three indices

\begin{tabular}{lccc}
\hline Yield & $\begin{array}{c}\text { Index of ear yield and all } \\
\text { characters }\end{array}$ & $\begin{array}{c}\text { Index of ear yield and ear } \\
\text { characters }\end{array}$ & $\begin{array}{c}\text { Index of ear yield and vigor } \\
\text { characters }\end{array}$ \\
\hline 1 & - & 1 & 1 \\
11 & 11 & 11 & - \\
25 & - & 25 & - \\
27 & - & 27 & - \\
32 & - & 32 & - \\
45 & 45 & 45 & - \\
54 & 54 & 54 & - \\
59 & - & 59 & - \\
69 & - & 69 & - \\
70 & 70 & 70 & 71 \\
\hline 84 & 71 & - & 84 \\
\hline
\end{tabular}

Table 8. Analysis of variance for the evaluation trail of the new $C_{1}$ synthetics for yield and yield components and agronomic characters in 2013 season

\begin{tabular}{|c|c|c|c|c|c|c|c|c|c|c|c|c|c|c|}
\hline \multirow[t]{2}{*}{ S.O.V. } & \multirow[t]{2}{*}{ d.f. } & \multicolumn{7}{|c|}{ Yield and yield components } & \multicolumn{6}{|c|}{ Agronomic characters } \\
\hline & & $\begin{array}{c}\text { Ear } \\
\text { yield } \\
(\mathrm{kg})\end{array}$ & $\begin{array}{c}\text { Ear } \\
\text { length } \\
(\mathrm{cm})\end{array}$ & $\begin{array}{c}\text { Ear } \\
\text { width } \\
(\mathrm{cm})\end{array}$ & $\begin{array}{c}100- \\
\text { kernel } \\
\text { weight } \\
(\mathrm{g}) \\
\end{array}$ & $\begin{array}{c}\text { No. } \\
\text { of } \\
\text { rows/ } \\
\text { ear } \\
\end{array}$ & $\begin{array}{l}\text { No. of } \\
\text { kernels/ } \\
\text { row }\end{array}$ & $\begin{array}{c}\text { Kernel } \\
\text { depth } \\
(\mathrm{cm})\end{array}$ & $\begin{array}{c}\text { No. of } \\
\text { days to } \\
50 \% \\
\text { Tasseling } \\
\end{array}$ & $\begin{array}{c}\text { No. of } \\
\text { days to } \\
50 \% \\
\text { Silking } \\
\end{array}$ & $\begin{array}{c}\text { Plant } \\
\text { height } \\
\text { (cm) }\end{array}$ & $\begin{array}{c}\text { Ear } \\
\text { height } \\
(\mathrm{cm})\end{array}$ & $\begin{array}{l}\text { Ear } \\
\text { leaf } \\
\text { area } \\
\left(\mathrm{cm}^{2}\right)\end{array}$ & $\begin{array}{c}\text { No. of } \\
\text { plants/ } \\
\text { plot }\end{array}$ \\
\hline Rep & 19 & & & & & & & & & 33.38 & & & 33803 & \\
\hline Popu & 5 & $0.602 * *$ & $10.1 * *$ & 0.4 & $39.4 *$ & $4.8 * *$ & $81.4 * *$ & $0.016^{* *}$ & & 7.05 & & $374.5 * *$ & 1695 & 8.73 \\
\hline Error & 95 & 0.136 & 1.7 & 0.2 & 14.2 & 0.8 & 13.4 & 0.005 & 3.25 & 3.79 & 240.4 & 99.7 & 3238 & 4.41 \\
\hline
\end{tabular}

$*, * *$; indicate significance at 0.05 and 0.01 levels of probability, respectively. 
Table 9. Means of " $\mathrm{C}_{1}$ " for different selection methods and their relative values with respect to " $\mathrm{C}_{0}$ " for yield and yield components and agronomic characters

\begin{tabular}{lcccccc}
\hline Characters & Check & $\mathbf{C}_{\mathbf{0}}$ & $\begin{array}{c}\text { Yield } \\
\left(\mathbf{C}_{\mathbf{1}}\right)\end{array}$ & $\begin{array}{c}\text { Yield and all } \\
\text { characters } \\
\left(\mathbf{C}_{\mathbf{1}}\right)\end{array}$ & $\begin{array}{c}\text { Yield ear } \\
\text { characters } \\
\left(\mathbf{C}_{\mathbf{1}}\right)\end{array}$ & $\begin{array}{c}\text { Yield and vigor } \\
\text { characters }\left(\mathbf{C}_{\mathbf{1}}\right)\end{array}$ \\
\hline Yield and yield components & & & & & & \\
Ear yield (kg)/ plot & 1.905 & 1.443 & 1.569 & 1.557 & 1.484 & 1.450 \\
& & $(1.00)$ & $(1.09)^{+}$ & $(1.08)$ & $(1.03)$ & $(1.01)$ \\
Ear length (cm) & 17.27 & 15.80 & 15.42 & 15.98 & 15.39 & 15.51 \\
& & $(1.00)$ & $(0.98)$ & $(1.01)$ & $(0.97)$ & $(0.98)$ \\
Ear width (cm) & 4.02 & 3.66 & 3.90 & 4.08 & 3.86 & 3.94 \\
& & $(1.00)$ & $(1.07)$ & $(1.12)$ & $(1.05)$ & $(1.08)$ \\
No. of rows/ ear & 13.60 & 13.85 & 15.05 & 14.00 & 14.10 & 14.10 \\
& & $(1.00)$ & $(1.09)$ & $(1.01)$ & $(1.02)$ & $(1.02)$ \\
No. of kernels/ row & 32.75 & 29.60 & 27.15 & 29.95 & 28.80 & 27.55 \\
& & $(1.00)$ & $(0.92)$ & $(1.01)$ & $(0.97)$ & $(0.93)$ \\
100-kernel weight & 28.42 & 26.12 & 29.87 & 28.97 & 29.97 & 29.00 \\
(kg) & & $(1.00)$ & $(1.14)$ & $(1.11)$ & $(1.15)$ & $(1.11)$ \\
Kernel depth (cm) & 0.93 & 0.88 & 0.94 & 0.92 & 0.87 & 0.88 \\
& & $(1.00)$ & $(1.06)$ & $(1.04)$ & $(0.99)$ & $(0.99)$ \\
Agronomic characters & & & & & & \\
50\% Tasseling & 64.0 & 62.9 & 64.1 & 63.1 & 64.1 & 63.6 \\
& & $(1.00)$ & $(1.02)^{*}$ & $(1.00)$ & $(1.02)$ & $(1.01)$ \\
50\% Silking & 67.4 & 66.6 & 67.9 & 66.5 & 67.7 & 67.5 \\
& & $(1.00)$ & $(1.02)$ & $(0.99)$ & $(1.02)$ & $(1.01)$ \\
Plant height (cm) & 197.5 & 204.9 & 216.7 & 217.0 & 211.2 & 207.2 \\
& & $(1.00)$ & $(1.06)$ & $(1.06)$ & $(1.03)$ & $(1.01)$ \\
Ear height (cm) & 98.4 & 99.3 & 109.2 & 105.5 & 99.6 & 100.1 \\
& & $(1.00)$ & $(1.10)$ & $(1.06)$ & $(1.00)$ & $(1.01)$ \\
Ear leaf area (cm $\left.{ }^{2}\right)$ & 553 & 580 & 566 & 567 & 569 & 575 \\
& & $(1.00)$ & $(0.98)$ & $(0.98)$ & $(0.98)$ & $(0.99)$ \\
\hline
\end{tabular}

+ The value between brackets indicates the relative value respective to $\mathrm{C}_{0}$.

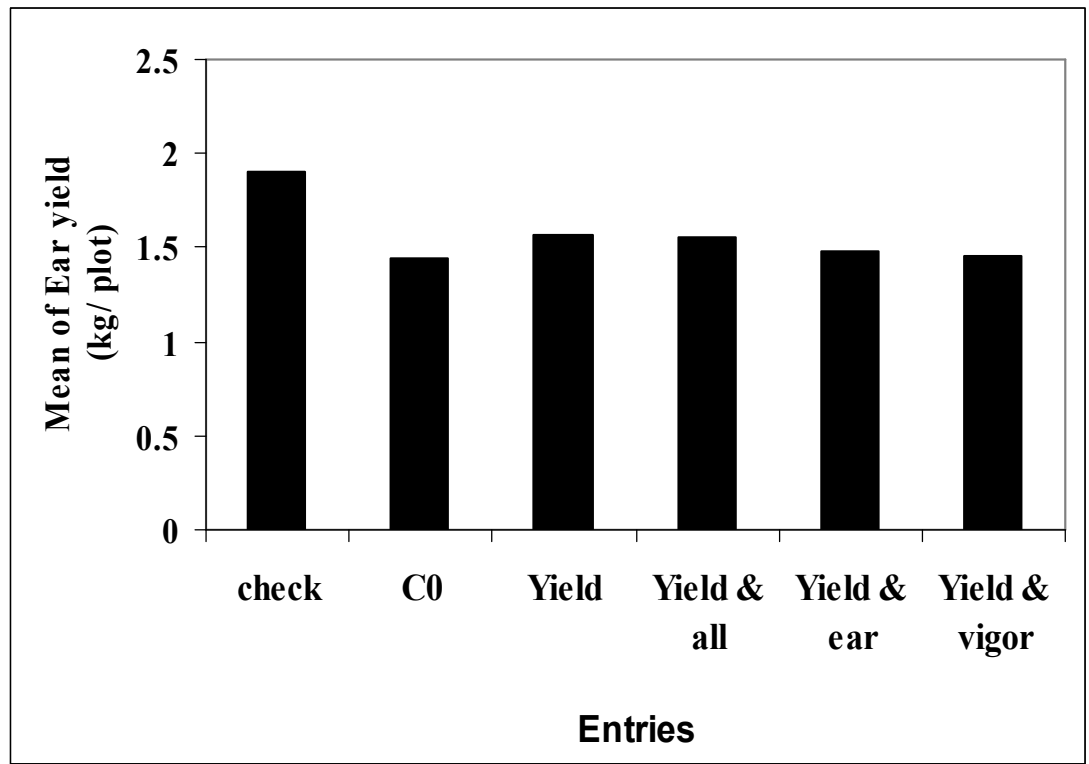

Figure 1. Means of yield $(\mathrm{kg} / \mathrm{plot})$ for check cultivar, $C_{0}$ and the four $C_{1}$-cycles of the four selection method 
This could be done by adding new $\mathrm{S}_{1}$ lines from new promising sources of maize populations and evaluating them with new $\mathrm{S}_{1}$ lines isolated from the $\mathrm{C}_{1}$ of (Composite - 21) by evaluating the isolated lines of $\mathrm{C}_{1}$ and $\mathrm{S}_{1}$ from the new sources together and selecting the best families from both, then crossing these selected families in isolation to form new cycle of improved (Composite - 21).

Comparing the advance from selection based on yield alone with selection based on index. The use of indices had a slight advantage over yield alone, and this might be due to the low estimates of heritability for most studied characters. This might be due to the inaccurate estimation of the nine characters and the C.V values for these characters were relatively high.

In the present study, the evaluation trials of the isolated families was conducted on one location only so, the effect of $\mathrm{G} \times \mathrm{E}$ interaction was included in the estimates of genetic variance and this might overestimate the predicted advance from selection. In the future studies, the isolated families should be evaluated in at least two locations, and it will be evaluated in index containing yield and one or two characters only to overcome the antagonism between characters. In future studies also, other characters could be included in the index, i.e., number of ears/ plant, tassel branches number, flag leaf size and leaf angle (erect leaf).

\section{REFERENCES}

Ajala, S. O., C. E. Ago, and G. Olaoye, (2009). Comparison of predicted responses to three types of recurrent selection procedures for the improvement of a maize (Zea mays L.) population. J. of Plant Breeding and Crop Sci., 1: 284292.
Ashgar, M.J. and S.S. Mehdi. (2010). Selection indices for yield and quality traits in sweet corn. Pak. J. Bot., 42: 775-789.

Badu-Apraku, B., A. F. Lum, M. A.B. Fakorede, A. Menkir, Y. Chabi, M. Abdulai, S. Jacob and S. Agbaje. 2008. Performance of early maize cultivars derived from recurrent selection for grain yield and Striga resistance. Crop Sci., 48: 99-112.

Betran, F.G. (1999). Applied quantitative genetics in plant breeding. Unpublished class notes. Texas, A \& $\mathrm{M}$ University Texas, USA.

Falconers, D.S. (1981). Introduction to quantitative genetics. $2^{\text {nd }}$ ed. Longman group(FE) Ltd., London, U. K.

Gomez, K.A. and A.A. Gomez (1984). Statistical Procedures for Agriculture Research. An International Rice Research Institute Book, John Wiley and Sons. Inc. New York.

Habliza, A.A. (2001). Methods for comparing the breeding potentiality of new maize populations. Ph.D. Thesis, Fac. of Agric., Alexandria Univ., Alexandria, Egypt.

Haullauer, A. R. and N. B. Miranda. (1981). Quantitative genetics in maize breeding. Iowa Stat. Univ.; Ames., Iowa, U.S.A.

Hazel, L. H. and J. L. Lush. (1942). Efficiency of three methods of selection. J. Hered. 33: 393-399.

Jones, D. F., (1924). The attainment of homozygosity in inbred strains of maize. Genetics 9: 405-418.

Mwimali, M., J.Derera, S. Mugo and P. Tongoona. (2015). Response to $S_{1}$ recurrent selection for resistance to two stem borers, Busseola fusca and Chilo partellus, in two tropical maize populations. Euphytica, 206: 711-723.

SAS, Institutes, Inc. (2007). SAS Technical Report SAS/ STAT Software: Change and Enhancements users Guide, Volume 2, Version 9.1.3, Fourth Edition Cary, Nc: SAS Institute, Inc.

Shull, G.H. (1908). The composition of a field of maize. Rep. Am. Breed. Assoc. 4,296-301. Jones,

Smith, H.F. (1936). A discriminant function for plant selection. Ann. Eugenics. London. 7: 240-250.

Sprague, G.F. and B. Brimhall. (1950). Relative effectiveness of two systems of selection for oil content of the corn kernel. Agron. J. 42: 83-88. 


\section{الملخص العربي}

\section{زيادة كفاءة الاتخاب الاورى للمحصول فى الأرة الشامية}

محمد ممدوح الروبى، محمد حسن الثيخ وشيماء محمود عوض الله

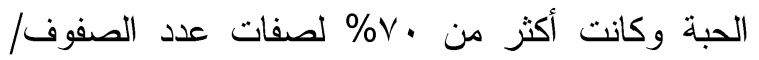
كوز ، وكلاً من صفتى ارتفاع النبات و الكوز .

ووبوجه عام كان الارتباط الوراثى ما بين صفة المحصول

مع الصفات الأخرى متوسط. -بناء على التقام المتوقع من الإنتخاب، فإن التحسن فى ملى المحصول والناتج عن استخدام دلائل الانتخاب كان

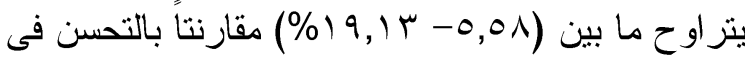
المحصول والناتج عن الانتخاب لصفة المحصول فقط ولذلك فإن استخدام دلائل الانتخاب كان له تفوق بسيط على الانتخاب للمحصول فقط. -التحسن الفعلى فى المحصول كان 9\% فى حالة الانتخاب لمحصول الكيزان فقط، ^ر في حالة استخدام دليل انتخاب يشتمل على كل الصفات المدروسة، باء في حالة استخدام دليل انتخاب يشتمل على صفات المحصول ومكوناته فقط، و ا\% لدليل الانتخاب الذى يشتمل على المحصول و الصفات النباتية. -التقدم المتوقع من الانتخاب كان أعلى من التقدم الفعلى فى

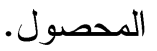

الهدف من الدراسة الحالية هو زيادة كفاءة الإنتخاب الدورى فى صنف الذرة التركيبى (Composite-21) وذللك بإستخدام دليل الإنتخاب لزيادة كفاءة تقييم عائلات الجيل الأول من

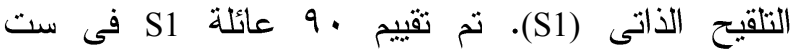
مجموعات، كل مجموعة أثنتملت على 10 عائلة كررت ثلاث مر ات فى تصميم قطاعات عشو ائية كاملة. -تم الثقييم بقياس عدد من الصفات المحصولية والنباتية وذلك لإجراء ستة طرق من الإنتخاب، إحدى هذه الطرق مبنى على أساس الإنتخاب للمحصول فقط، أما هاء الخمس طرق الأخرى مبنية على الانتخاب بإستخدام

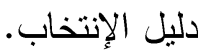

- تم تقدير التباين البيئى الوراثى م ومعامل التوريث (H\%) بالمعنى الواسع لكل صفة وذلك للتتبؤ بالتقدم المنوقع من مختلف طرق

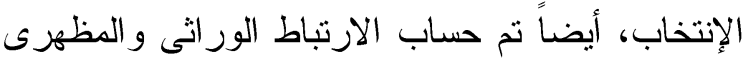
ما بين الصفات وذللك لإختبار إمكانية الانتخاب غير المباثر للمحصول باستخدام بعض الصفات الأخرى و التى لها ارتباط وراثى عالى بالمحصول. -تقديرات معامل التوريث كانت منوسطة(1)-00\%) لصفات محصول الكيزان، وزن المائة حبة، وعمق 